however, particularly in the unmarried, that the cervix will just allow the uterine sound to pass through a mucous membrane so diseased as not to be willing to get well unless it be touched with a strong acid. After applying the acid nitrate of mercury or nitric acid to the cervical canal in such cases, the practitioner had better examine the patient every week, and pass into the cervical canal a pencil laden with a solution of nitrate of silver, or, at the end of two or three months, he would have the annoyance to find that his treatment has induced cervical stricture.

A third and less numerous class of patients comprise women in whom long continued chronic cervicitis is accompanied by considerable hard hypertrophy of the cervix, inflammation of the mucous membrane having caused its surrounding tissues to become hypertrophied. Sometimes the enlargement of both the body and the neck of the womb appears to have begun in defective uterine involution. At all events, when I am consulted on such cases, they have lasted seven or eight years, or longer, to the misery of the patient, to the calamity of the family, and to the opprobrium of the profession, for such cases go the round of all those who are accepted as authorities for diseases of women. The patients do not get cured, because consulting men have no faith in the only way of curing such cases - the application of potassa fusa cum calce, or some equally strong caustic, to the cervical canal. Dr. H. Bennet put this forcibly before the profession twenty years ago. He made converts of Sir James Simpson and of many eminent practitioners in this and in other countries; and I discussed, in the best way I could, this mode of treatment, in all its bearings, in thirty pages of my Hanclbook. The treatment is solidly based on the recognised utility of caustics in a host of surgical complaints, and it has been well established by the Lyons school of medicine; but when such patients come and tell me what they have had done to them by men in authority, I never learn that a strong caustic has ever been applied. I hear of long ineffectual treatment with nitrate of silver, of an acid having been used, of a pessary to support the womb, of uterine dilatation, of division of the cervix, or of the leaving in the womb of one of those thirty intrauterine pessaries which were handed round on a tray, one night when I had the honour of presiding over the Obstetrical Society of London. I even have heard that there are practitioners who believe that they can benefit their patients by introducing the index into the vagina, to attempt to rectify a moderate amount of uterine displacement, three times a week, for two or three months; but I never hear that trial has been made of the only mode of treatment likely to effect a radical cure of these cases.

To resume the preceding remarks : instead of advising nitric acid in all cases of cervical disease requiring a caustic, as Ur. Braithwaite seems to do, I now hold-r. That, in comparatively recent cases of endocervicitis, nitrate of silver, tincture of iodine, or carbolic acid, suffices; 2. That chronic cases of endocervicitis had best be treated by acid nitrate of mercury or nitric acid; 3 . That hyperchronic endocervicitis with considerable cervical hypertrophy requires potassa fusa cum calce, or some strong acid.

Since these remarks were penned, Dr. F. Churchill of Dublin has endorsed Dr. Braith waite's views respecting the all-sufficiency of nitric acid in all cases of chronic cervical inflammation, and I am sorry to differ from so eminent a pathologist.

\section{THE PRESENT EPIDEMIC OF SCARLET FEVER IN BRISTOL.}

By DAVID DAVIES, M.R.C.S.Eng., Medical Officer of Health for the City.

\section{II.}

Sceptical Misgivings regardins our Present Hy'sienic Views and Practice with regard to Scarlet Fever. - One failure starts a doubt in a believer's mind ; a second confirms it; a series of failures makes one look out for a better creed. Are we doing any good with our present preventive means? If they could be universally enforced, as they have been in isolated families with disciplined minds, I grant they would succeed ; but when this is attempted with large thickly packed communities, can they be, or have they ever been, successfully enforced? By the imperfect execution of them through the length and breacith of the land, do we increase or lessen the mortality from disease? I feel certain that we increase the anxiety of the domestic and social troubles of the public by our preventive measures ; and I feel doubtful of the answer to the former question. Take, for example, an imaginary but typical case in private practice.

There is a family named $X$., in easy circumstances. They have five children-three boys and two girls. There is an epidemic, of a very mild type, of scarlet fever in the locality. Hundreds have had the disease ; but there has been no death. The season is July; the weather rainy, the atmosphere moist. The youngest boy, aged 4 , contracts the disease in the prevalent mild type. The other four children, by the advice of their medical attendant, are sent to a distance, and escape the infection. The sick child recovers. Two years elapse. The eldest son goes to Eton, Rugby, Marlborough, or some other public school. An epidemic of a severe type has just broken out where he is ; he contracts the disease. The parents are telegraphed for to see their son, supposed to be dying. They travel to and fro three hundred miles. The patient ultimately recovers, and escapes only by the skin of his teeth. The school is temporarily broken up. The convalescent is sent to a fashionable watering place before he is properly disinfected, and there he spreads the disease. The second son has escaped, through being kept at a distance from his brother. He has, in the course of time, taken his degree at college; has been admitted as a barrister; has, after a long struggle, made his position; has been married. IIe passes through Yaris on his honeymoon. The weather is cold, the wind easterly. In Paris, an epidemic of scarlet fever prevails. He contracts the disease, and dies in a strange land; and leaves his young bride a widow among strangers. In time, the eldest girl is married to a rich man. She is in due time confined of her first-born. The bells are ringing, and all goès on merrily as a "marriagre bell". A fortnight afterwards, that house is desolate. In that house are now only a bereaved husband and a motherless infant ; the subtle seeds of this mysterious disease have been inadvertently introduced to the puerperal patient in the nurse's shawl, or on the sleeve of the doctor's coat. I will not follow this case further; but ask, in all seriousness, would not life and suffering have been saved if all this family had been allowed to pass through the disease when it first appeared among them in a mild type, when they were all children? I wish it to be thoroughly uuderstood that, as a health-officer, I have never had the moral courage to discard my former profession of faith, and to undertake the responsibility of giving practical effect to my doubts. I have never used disinfectants so extensively as during the present epidemic, and yet our failure is complete.

The doubts I have expressed do not in any way extend to typhus and enteric fevers, small-pox, and Asiatic cholera.

It is a fact beyond contradiction that occasionally this tiger of pathology seems to stalk abroad, having left both claws and teeih at home. Could we not play with him then? Inoculation from mild cases of variola previous to the discovery of vaccination proved of immense benefit. We cannot inoculate scarlet fever, but it can be imported. We can choose our type and season of the year. I lay these thoughts before the profession most humbly, "seeking for more light" under a failure in the midst of a great epidemic. I have never practised the suggestions, either in public or private, except in my own family, and with my own children, and these, thank God, with the best result.

Is there a milder exanthem of an alivid stecies that can provent or modify' this disease? - Rötheln is nearly allied ; is very infectious, but harmless. Does it modify scarlet fever, or is it modiliced by it? I have for some time looked upon it with affection, but am afraid to theorise on the subject. Can anyone throw light on this unexplored field? Observation convinces me that there is some unknown condition which gives immunity to some persons from scarlet fever: what is this condition? An analogous condition was known in the Vale of Berkeley regarding small-pox before the days of Jenner, and might have remained unknown to the outer world had not that great man unearthed it.

Who will be the Jenner of scarlet fever?

This pest, which broke out in Italy about the midlile of the seven-, teenth century, is now two hundred years oid. It has surely committed havoc enough amons our race. In the hind provision of nature, there must be an anticlote somewhere. Who will discover it?

A Delusion concerning Bristol. - It appears in some of the daily metropolitan papers that there is an impression abroad that my good and talented friend Dr. William Budd succeeded in preventing epidemics of scarlet fever; and that he was in some way or anotier connected with our sanitary arrangements. Both these views are erroneous. Scarlet fever was never more prevalent and more fatal in Bristol than when Dr. Budd was at the zenith of his well-deserved fame. No family suffered more severely than his own. He lost his eklest son from the disease-a blow from which, I believe, he never fully recovered. $\mathrm{He}$ could never mention his loss to me without tears. In individual and isolated families, his instructions have succeeded, but not on a large scale. My good, kind, and most talented friend Dr. Budd had never any connection with the sanitary arrangements of Bristol, either as director or as administrator. 